\title{
Ações de impacto desenvolvidas pelo Coletivo Socioambiental Sementes da Gratidão: A Educação Ambiental aplicada por meio da mobilização social
}

\section{Impact actions developed by the Sementes da Gratidão Socioenvironmental Collective: Environmental Education applied though social mobilization}

\section{Zoziane Bernardo Tolentino $^{1}$}

O Coletivo Socioambiental Sementes da Gratidão trata-se de uma Organização da Sociedade Civil, sem fins lucrativos que desenvolve ações de Impacto Socioambiental positivo no município de Conceição da Barra - Espírito Santo. Por meio de mobilizações comunitárias e em busca de promover conexões sociais, estimula a articulação entre comunidades periféricas urbanas e tradicionais.

As ações são pautadas no fortalecimento dessas comunidades por meio de intervenções sociais colaborativas que vão desde arrecadações e entregas de itens básicos de sobrevivência (alimentos e roupas), atividades ambientais (recuperação de nascentes, limpeza de áreas naturais e recuperação de áreas degradadas) e por meio da difusão de acesso a informações.

Conceição da Barra possui uma população estimada de 31.273 (IBGE, 2020), apesar de colonizada por portugueses, o município não teve uma vida cultural restrita a padrões europeus. $\mathrm{O}$ município apresenta uma memória viva de resiliência cultural, com a existência de treze comunidades remanescentes de quilombos certificadas (PALMARES, 2021). Apresenta também em seu histórico a presença notória de indígenas que ali viveram (PMCBARRA, 2017), no entanto, nos dias atuais seus descendentes se encontram localizados em locais classificados como comunidades rurais (CEPEMAR, 2004).

Esses povos tradicionais (quilombolas e indígenas) expressam historicamente o cuidado e respeito com o meio ambiente em sua integralidade, entendendo o mesmo como fundador do Ser e criador de Vida. São populações as quais se configuram como mantenedoras dos cuidados com a Terra, com a luta pela sobrevivência em Comunidade, representantes da resistência Cultural e da constante busca por conexões com o Sagrado baseadas em suas crenças e cosmologia em relação à natureza.

1 Bióloga e Fundadora do Coletivo SocioambientalSementes da Gratidão.E-mail: zozianebernardo@hotmail.com 
Partindo do preceito que conhecimentos e conceitos são constituídos a partir de percepções advindas de vivências e experiências no contexto no qual o indivíduo está inserido, a Educação Ambiental por sua vez, pode se tornar um caminho para construção de diálogos. Loureiro (2020) enfatiza que na Educação, o diálogo é exigência para potencializar os saberes que se entrecruzam, organizando práticas e possibilitando a criação livre do conhecimento.

Sendo assim, o Coletivo Socioambiental Sementes da Gratidão baseia suas ações na Educação Ambiental utilizando-a como porta de entrada para os caminhos diante do saber. A partir de conhecimentos empíricos existentes dentro de comunidades locais e através da contextualização com os saberes científicos busca-se maior envolvimento comunitário, engajamento social, e consequentemente maior acesso às informações e construção coletiva de conhecimentos.

É válido lembrar que aproximações entre setores dos movimentos sociais e dos movimentos ambientalistas foram às frentes as quais deram origem ao que ficou conhecido como socioambientalismo, período próximo ao que a Educação Ambiental se constituiu (LIMA, 2009). Portanto, unir forças em prol de um bem comum pode também ser entendido como um pilar da Educação Ambiental.

Em um âmbito acadêmico (LAYRARGUES \& LIMA, 2014) conceituam as vertentes de Educação Ambiental em três linhas: A Conservacionista, aquela com pensamento sistêmico e holístico vinculada a princípios da ecologia; a Pragmática a qual vincula o pensamento sistêmico ao conceito de desenvolvimento sustentável, e por fim a vertente Crítica, a qual aglutina as vertentes da Educação Ambiental popular, emancipatória e transformadora, ampliando assim caminhos de conhecimentos e possibilidades de diálogos.

Contudo, é conveniente ressaltar que se partíssemos da conceituação da Educação com uma configuração baseada na cocriação por meio de vivências e experiências, a separação do termo “Ambiental” se faria desnecessário. Mas é relevante também reafirmar que a Educação Ambiental propõe a integralidade, fato que é possível enxergar em sua trajetória histórica de seus primeiros passos de composição no Brasil (LIMA, 2009). Tal plenitude entre o social e o ambiental se relaciona diretamente com a dinâmica de vivência dos povos tradicionais, e um exemplo corriqueiro para essas comunidades se dápela reverência e cuidado de mestres e mestras quilombolas e indígenas em relação às ervas medicinais.

Por essa razão, o Sementes da Gratidão é uma instituição a qual se empenha em promover ações coletivas, primando pelo resgate das raízes da Educação Ambiental baseada em movimentos populares, utilizando-se da abertura advinda das nuances entre as vertentes Conservacionista, Pragmática e Crítica, propondo a dialogicidade entre elas. Buscand o continuamente a construção de diálogos entre os saberes tradicionais e os saberes acadêmico científicos, e partindo do preceito que nenhum conceito encontra-se totalmente fechado ou acabado, que limitar a construção de diálogos a 
vertentes únicas é privar comunidades de fazer escolhas e que propor fracionalidade entre saberes é desvalorizar conhecimentos ancestrais de sobrevivência e conexão com a natureza.

Portanto a educação para a justiça ambiental vai além das resoluções de conflitos, visa à proteção ambiental indo contra a segregação sócio cultural e propondo equidade de acesso ao Meio Ambiente em sua totalidade.

\section{REFERÊNCIAS}

CEPEMAR - SERVIÇOS DE CONSULTORIA EM MEIO AMBIENTE LTDA (Espírito Santo). Petrobras - Petróleo Brasileiro S.A (org.). Plano de manejo do Parque Estadual de Itaúnas. Vitória, 2004. Disponível em: https://iema.es.gov.br/PEI. Acesso em: 23 jun. 2021.

FUNDAÇÃO CULTURAL PALMARES (org.). Certificação Quilombola: comunidades certificadas. Comunidades certificadas. 2021. Disponível em: http://www.palmares.gov.br/? page_id=37551. Acesso em: 17 jun. 2021.

IBGE (org.). Cidades e Estados: conceição da barra. Conceição da Barra. 2021. Disponível em: https://www.ibge.gov.br/cidades-e-estados/es/conceicao-da-barra.html. Acesso em: 20 jun. 2021.

LAYRARGUES, P. P.; LIMA, G. F. - As macrotendências politico-pedagógica da educação ambiental brasileira. Ambiente \& Sociedade. São Paulo, v. XVII, n. 1, p. 23-40 jan-mar 2014.

LIMA, G. F. da C. Educação ambiental crítica: do socioambientalismo às sociedades sustentáveis. Educação e Pesquisa, São Paulo, v.35, n.1, p. 145-163, jan./abr. 2009.

LOUREIRO, C. F. B.. Contribuições teórico-metodológicas para a educação ambiental com povos tradicionais. Revista eletrônica ensino, saúde e ambiente, v. 1, p. 131-144, 2020.

PMCBARRA. Pmcbarra (org.). Nossa História. 2017. Disponível em: https://conceicaodabarra .es.gov.br. Acesso em: 22 jun. 2021. 